-Full Paper-

\title{
Synergistic Role of Igf2 and DIk1 in Fetal Liver Development and Hematopoiesis in Bi-Maternal Mice
}

\author{
Qiong WU ${ }^{1 \#}$, Manabu KAWAHARA ${ }^{1)}$ and Tomohiro KONO ${ }^{1)}$ \\ ${ }^{1)}$ Department of BioScience, Tokyo University of Agriculture, Tokyo 156-8502, Japan \\ \#Present: Department of Life Science and Engineering, Harbin Institute of Technology, Harbin 150001, China
}

\begin{abstract}
Mouse bi-maternal embryos (BMEs) that contain two haploid sets of genomes from non-growing (ng) and fully-grown (fg) oocytes develop to embryonic day (E) 13.5. However, the $\mathrm{ng} / \mathrm{fg}$ BMEs never develop beyond E13.5 because of repression of the paternally expressed imprinted genes, Igf2 and Dlk1. The present study was conducted to address the issue of whether fetal hematopoietic disorder is involved in the restricted development of BMEs. FACS analysis revealed that the livers of $\mathrm{ng}^{\mathrm{wt}} / \mathrm{fg}$ BMEs contained increased numbers of immature $\mathrm{c}^{-\mathrm{kit}^{+}} / \mathrm{ter}^{-119^{-}}$ hematopoietic cells, were while the numbers of mature c-kit ${ }^{-} /$ter $119^{+}$hematopoietic cells were decreased. This finding was supported by histological observations. Quantitative gene expression analysis revealed that Igf2 and Dlk1 expression was repressed in the liver. To understand the role of paternally-methylated imprinted genes on chromosomes 7 and 12, particularly Igf2 and Dlk1, in fetal liver hematopoiesis, we constructed $\mathrm{ng}^{\Delta \mathrm{ch} 7} / \mathrm{fg}, \mathrm{ng}^{\Delta \mathrm{ch} 12} / \mathrm{fg}$ and $\mathrm{ng}^{\Delta \text { Double }} / \mathrm{fg}$ BMEs using $\mathrm{ng}$ oocytes harboring deletion of differentially methylated regions at distal chromosomes 7 and/or 12. The $\mathrm{ng}^{\Delta \mathrm{ch} 7} / \mathrm{fg}, \mathrm{ng}^{\Delta \mathrm{ch} 12} / \mathrm{fg}$ and $\mathrm{ng}^{\Delta \mathrm{DDouble}} / \mathrm{fg}$ BMEs, respectively, express Igf2, Dlk1 and both, and these embryos developed to term with specific phenotypes; the $\mathrm{ng}^{\Delta \mathrm{ch}} / \mathrm{fg}$ and $\mathrm{ng}^{\Delta c h 12} / \mathrm{fg}$ BMEs develop to term with severe growth retardation, and the $\mathrm{ng}^{\Delta \mathrm{D} \text { Doble }} / \mathrm{fg}$ BMEs can survive to become normal female adults. By inducing Igf2 and Dlk1 expression, the proportions of mature and immature hematopoietic cells in the livers of the $\mathrm{ng}^{\Delta \mathrm{ch} 7} / \mathrm{fg}, \mathrm{ng}^{\Delta \mathrm{ch} 12} / \mathrm{fg}$ and $\mathrm{ng}^{\Delta \text { Double }} / \mathrm{fg}$ BMEs were considerably restored, and particularly in the $\mathrm{ng}^{\Delta \text { Double }} / \mathrm{fg}$ BMEs, hematopoiesis occurred normally with appropriate expressions of the related genes. These data suggest that inappropriate expression of Igf 2 and Dlk1 is involved in impaired fetal hematopoiesis.
\end{abstract}

Key words: Dlk1, Genomic impringing, Hematopoiesis, Igf2, Liver, Mouse

(J. Reprod. Dev. 54: 177-182, 2008)

D ue to imprinted genes, which exhibit monoallelic expression depending upon parental origin-dependent epigenetic modifications, such as DNA methylation imposed during gametogenesis, mouse parthenogenetic embryos never develop beyond day 10 of gestation in mice [1-4]. However, reconstructed bi-maternal embryos (ng/fg BMEs), which contain 2 haploid sets of genomes obtained from a non-growing stage oocyte (ng) and a fully grown oocyte (fg), develop to embryonic day (E) 13.5 [5]. A detailed gene expression analysis revealed that this extended development of ng/fg BMEs results from the appropriate expression of a majority of the imprinted genes: however, the paternally-methylated and paternally-expressed genes are still repressed $[6,7]$. To induce expression of Igf2 and Dlk1 from the ng oocyte allele, we reconstructed ng/fg BMEs using ng oocytes harboring a deletion in the $H 19$ transcription unit and its differentially methylated region $(\Delta$ ch7) or a deletion in the methylated region IG-DMR $(\Delta \mathrm{ch} 12)$ in the ng allele. We demonstrated that both genotypes of $\mathrm{ng}^{\Delta \mathrm{ch} 7} / \mathrm{fg}$ BMEs [7] and $\mathrm{ng}^{\Delta \mathrm{ch} 12} / \mathrm{fg}$ BMEs [8] developed to E18.5, but also that they experienced severe growth retardation and died soon after recovery from the uterus. Furthermore, we recently demonstrated that ng/fg BMEs harboring both $\Delta$ ch7 and $\Delta$ ch12 ( $\Delta$ Double) expressed $I g f 2$ and $D l k 1$ at appropriate levels and developed to normal adults at high frequency [9]. From these results, it has been

Accepted for publication: February 13, 2008

Published online: March 13, 2008

Correspondence: T. Kono (e-mail: tomohiro@nodai.ac.jp) suggested that both $I g f 2$ and Dlk1 are critical for normal mouse embryonic development, while these paternally expressed imprinted genes function as a strict barrier to development beyond mid-gestation (E13.5) in mice [7, 8, 10].

However, phenotypical analyses for ng/fg bi-maternal fetuses have rarely been reported. In order to gain a further understanding of the features of the bi-maternal fetuses, we focused on hematopoiesis because the fetal hematopoietic system in the liver is critically important for survival and growth of mouse embryos. In mouse embryos, fetal hematopoietic systems dynamically change during development; the yolk sac (YS) [11], aorta-gonad-mesonephros (AGM) [12-14] and placenta (PL) [15] have been reported as the origins of hematopoietic stem cells (HSCs) during early gestation. Beginning in mid-gestation, the fetal liver, in which hematopoietic stem cells (HSCs) relocate from multiple sources and colonize, functions as a major hematopopietic organ, and subsequently, hematopoiesis permanently occurs in the bone marrow throughout life [16]. Interestingly, it is known that the Igf2 and Dlk1 genes are involved in fetal hematopoiesis in the fetal liver. The Igf2 gene, which encodes a growth-promoting factor insulinlike growth factor 2 (IGF-II), plays a potential role for the growth of fetal and hematopoietic stem cells [17]. Dlk1 encodes delta-like homolog 1 , a cell-surface transmembrane secreted protein belonging to the epidermal growth factor-like homeotic family that also appears to play significant roles for normal hematopoiesis [18, 19].

In the present study, we conducted histological and gene expres- 
Table 1. Primers used for quantitative gene expression analysis by real time PCR

\begin{tabular}{llc}
\hline Genes & \multicolumn{1}{c}{ Primer sequences } & GenBank accession No. \\
\hline Igf2 & 5'-AGGGGAGCTTGTTGACACG-3' & NM-010514 \\
Dlk1 & 5'-GGGTATCTGGGGAAGTCGTC-3' & \\
& 5'-ACTTGCGTGGACCTGGAGAA-3' & NM-010052 \\
GATA1 & 5'-CTGTTGGTTGCGGCTACGAT-3' & \\
& 5'-CTC TAC CCT GCC TCA ACT G-3' & NM-008089 \\
EpoR & 5'-TTG CTG ACA ATC ATT CGC TT-3' & \\
& 5'-TTCACCCAACGCTTGGAAGAC-3' & NM-010149 \\
EKLF & 5'-ATGCGGTGATAGCGAGGAGAA-3' & \\
& 5'-CGGGAGAGAAGCCTTATGCC-3' & NM-010635 \\
NF-2E & 5'-GGTGACGCTTCATGTGCAGA-3' & \\
GAPDH & 5'-ACGTGGACATGTACCCAGTGG-3' & NM-008685 \\
& 5'-GCCACCTTGTTCTTGCCCCGT-3' & \\
& 5'-GTCGTGGAGTCTACTGGTGTC-3' & NM-199472 \\
\hline
\end{tabular}

sion analyses in the fetal livers of ng/fg bi-maternal embryos, and performed a FACS analysis of fetal liver cells to demonstrate the differentiation of erythroid cells using antibodies against ter119, a mouse erythroid-specific marker, and c-kit, a marker for immature hematopoietic cells. The results showed defection of fetal liver development and hematopoiesis in the ng/fg BMEs, suggesting a synergistic role for paternally methylated imprinted genes on chromosomes 7 and 12 in fetal liver development and hematopoiesis in the bi-maternal mouse fetuses. The defective liver development and hematopoiesis could be one of the causes of arrested development in the ng/fg BMEs.

\section{Materials and Methods}

\section{Nuclear transfer}

The ng $^{\text {wt }} / \mathrm{fg}, \mathrm{ng}^{\Delta \mathrm{ch} 7} / \mathrm{fg}, \mathrm{ng}^{\Delta \mathrm{ch} 12} / \mathrm{fg}$ and $\mathrm{ng}^{\Delta \text { Double }} / \mathrm{fg}$ BMEs were reconstructed according to our previous reports [7]. In brief, fully grown germinal vesicle $(\mathrm{GV})$ oocytes were collected into M2 medium from the ovarian follicles of B6D2F1 (C57BL/6N $\times$ DBA) female mice 44-48 h after they were injected with equine chorionic gonadotrophin. Ovulated MII oocytes were also collected from superovulated B6D2F1 mice $16 \mathrm{~h}$ after they were injected with human chronic gonadotrophin. We collected ng oocytes that were in the diplotene stage of first meiosis from the ovaries of 1-day-old newborn mice. The GV oocytes were manipulated in M2 medium containing $200 \mu \mathrm{M}$ dbcAMP and 5\% calf serum throughout the experiment. The ng oocytes were fused with enucleated GV oocytes by using inactivated Sendai virus (HVJ, 2700 hemagglutinating activity unit/ml). The reconstructed oocytes were cultured for $14 \mathrm{~h}$ in $\alpha$-MEM medium (GIBCO, Grand Island, NY, USA) containing $5 \%$ calf serum. A spindle from the reconstructed oocytes was again transferred into ovulated MII oocytes, followed by treatment with $10 \mathrm{mM} \mathrm{SrCl} 2$ in $\mathrm{Ca}^{2+}$-free M16 medium for $2 \mathrm{~h}$. These embryos were cultured in M16 medium for 3.5 days in an atmosphere of $5 \% \mathrm{CO}_{2}, 5 \% \mathrm{O}_{2}$ and $90 \% \mathrm{~N}_{2}$ at $37 \mathrm{C}$. The embryos that developed to the blastocyst stage were transferred into the uterine horns of recipient female mice at 2.5 days of pseudopregnancy.
All the mice were maintained and used in accordance with the guidelines for the care and use of laboratory animals specified by the Japanese Association for Laboratory Animal Science and by the Tokyo University of Agriculture.

\section{Histological analysis}

For histological analysis, the livers of mouse BMEs (ng ${ }^{\mathrm{wt}} / \mathrm{fg}$, $\mathrm{ng}^{\Delta \mathrm{ch} 7} / \mathrm{fg}, \mathrm{ng}^{\Delta \mathrm{ch} 12} / \mathrm{fg}$ and $\mathrm{ng}^{\Delta \text { Double }} / \mathrm{fg}$ ) and control embryos (wt) at day 12.5 of gestation were fixed overnight in $4 \%$ paraformaldehyde (Sigma-Aldrich Chemical, St. Louis, MO, USA) in PBS at 4 C. Next, formalin-fixed paraffin-embedded sections of the livers were stained with hematoxylin and eosin (HE) using standard techniques.

\section{In situ hybridization (ISH)}

At day12.5 of gestation, the livers of the BMEs (ngwt/fg, $\mathrm{ng}^{\Delta \mathrm{ch} 7} /$ $\mathrm{fg}, \mathrm{ng}^{\Delta \mathrm{ch} 12} / \mathrm{fg}$ and $\mathrm{ng}^{\Delta \text { Double }} / \mathrm{fg}$ ) and control fetuses (wt) were fixed in $4 \%$ freshly prepared paraformaldehyde in PBS. The livers were incubated in 10-20\% graded sucrose and embedded in OCT compound (Sakura Finetechnical, Tokyo, Japan). Sections (10 $\mu \mathrm{m})$ of the liver tissues were placed on the slides, and ISH was performed essentially as described previously. Digoxigenin-labeled RNA probes for ISH were prepared using a DIG RNA labeling kit (Roche Diagnostics, Mannheim, Germany) according to the manufacturer's instructions. To obtain the RNA probes, cDNA fragments of Igf2 (primers: 5'-GAC TCT GTG CGG AGG GGA GC-3', and 5'-TCT TTG GGT GGT AAC ACG AT-3') and Dlk1 (primesr: 5'-CCT CTT GCT CCT GCT GGC TTT C-3' and 5'GAT GTG TTG CTC GGG CTG CTG A-3') were amplified by reverse transcriptase (RT)-PCR and inserted in a PGEM $^{\circledR}$-T Easy Vector (Promega, Madison, WI, USA).

\section{Quantitative analysis of gene expression}

At days 12.5, 15.5 and 18.5 of gestation, total RNA was extracted from the livers of the 4 genotypes of BMEs $\left(\mathrm{ng}^{\mathrm{wt}} / \mathrm{fg}\right.$, $\mathrm{ng}^{\Delta \mathrm{ch} 7} / \mathrm{fg}, \mathrm{ng}^{\Delta \mathrm{ch} 12} / \mathrm{fg}$ and $\mathrm{ng}^{\Delta \text { Double}} / \mathrm{fg}$ ) and the control (wt) using ISOGEN (Nippon Gene, Tokyo, Japan). The cDNAs were synthe- 
sized using a SuperScript ${ }^{\mathrm{TM}}$ III RNase $\mathrm{H}^{-}$Reverse Transcriptase kit (Invitrogen $^{\mathrm{TM}}$ ) in a reaction solution $(20 \mu \mathrm{l})$ containing total RNA ( $1 \mu \mathrm{g}$ ) prepared from the tissues. Subsequently, the cDNAs were used for quantitative analysis of genes expression. This analysis was performed using real-time quantitative PCR (LightCycler ${ }^{\mathrm{TM}}$ System; Roche Diagnostics) with a ready-to-use reaction mixture kit (LightCycler FirstStart DNA Master SYBR Green I; Roche Diagnostics). The sequences of the primers used for the PCR reaction and the corresponding GenBank accession numbers are listed in Table 1. The GAPDH gene was used as a loading control.

\section{Flow cytometry}

At E12.5, the livers of the BMEs (ng ${ }^{\text {wt }} / \mathrm{fg} \mathrm{ng}^{\Delta \mathrm{ch} 7} / \mathrm{fg}_{\mathrm{g}} \mathrm{nd}^{\Delta \mathrm{ch} 12} /$ fg) and controls (wt) were mechanically dissociated by pushing them with a syringe plunger through a $40-\mathrm{mm}$ strainer in the presence of phosphate-buffered saline (PBS) and $0.5 \%$ bovine serum albumin (PBS/0.5\% BSA). Single-cell suspensions $\left(5 \times 10^{5}\right)$ were immunostained for $1 \mathrm{~h}$ at $4 \mathrm{C}$ in $\mathrm{PBS} / 0.5 \%$ BSA with fluorescein isothiocyanate (FITC)-conjugated anti-c-Kit $(1 \mathrm{mg} / \mathrm{ml})$ antibodies and phycoerythrin (PE)-conjugated anti-Ter119 (1 mg/ml) antibodies (Pharmingen, San Diego, CA, USA). After 2 washes, flow cytometry was conducted on a Becton Dickinson FACSCalibur (Franklin Lakes, NJ, USA), and 10,000 events were acquired for each sample.

\section{Statistical analysis}

The difference in the levels of gene expression between the BME and control were determined by ANOVA and a $t$-test (a P value of less than 0.01 was considered statistically significant).

\section{Results}

\section{Histological examination of the fetal livers}

In E12.5 wt fetal livers, obvious intermingling of well-differentiated hematopoietic precursors and hepatic cells was observed in the parenchyma (Fig. 1A); however, differentiation was apparently abnormal in the ng ${ }^{\mathrm{wt}} / \mathrm{fg}$ BMEs. The number of parenchyma cells and hematopoietic precursors were decreased considerably in the unit area with increasing frequency of aggregated and/or fragmented nuclei in the liver of the ng ${ }^{\mathrm{wt}} / \mathrm{fg}$ BMEs (Fig. 1B). These prominent disorders were obviously restored in the livers of $\mathrm{ng}^{\Delta \mathrm{ch} 7} /$ fg, $\mathrm{ng}^{\Delta \mathrm{ch} 12} / \mathrm{fg}$ and $\mathrm{ng}^{\Delta \text { Double}} / \mathrm{fg}$ BMEs, which were morphologically similar to that of the wt liver (Figs. 1C, D and E). These results suggest that the differential disorders in the fetal liver cells might be involved in restricted development of ng ${ }^{\mathrm{wt}} / \mathrm{fg}$ BMEs to E13.5.

\section{Expression of Igf2 and Dlk1 in fetal livers}

To understand the liver-specific expression of the imprinted Igf2 and Dlk1 genes, quantitative gene expression and ISH analyses were performed at E12.5 (Figs. 2A). With regard to the $\mathrm{ng}^{\Delta \mathrm{ch} 7} / \mathrm{fg}$ and $\mathrm{ng}^{\Delta \mathrm{ch} 12} / \mathrm{fg}$ BMEs, the Igf2 and Dlk1 genes were inversely expressed and repressed and were $75 \%$ and $20 \%$ and $0.4 \%$ and $93 \%$ of those in the wt livers, respectively. The expression levels of both genes in the $\mathrm{ng}^{\Delta \text { Double }} / \mathrm{fg}$ BME livers were expressed at the same levels as those in the wt livers. In the ng $^{\mathrm{wt}} / \mathrm{fg}$ BME livers, expression of $I g f 2$ and Dlk1 was extremely low. To show tissue- specific expression, ISH analysis was carried out (Fig. 2B). Distinct signals for Igf 2 and Dlk1 in the parenchyma of the liver anlage were detected in the $\mathrm{ng}^{\Delta \mathrm{ch} 7} / \mathrm{fg}$ and $\mathrm{ng}^{\Delta \mathrm{ch} 12} /$ fg livers, respectively. In the $\mathrm{ng}^{\Delta \text { Double} / f g ~ B M E ~ l i v e r s, ~ b o t h ~ s i g n a l s ~ f o r ~ I g f 2 ~ a n d ~ D l k 1 ~ w e r e ~}$ detected clearly in parenchyma of the liver anlage.

\section{Definitive erythropoiesis in BMEs livers}

In order to obtain further insights into fetal hematopoiesis, we performed a FACS analysis of the fetal liver cells to demonstrate the differentiation of erythroid cells using antibodies against ter119, a mouse erythroid-specific marker, and c-kit, a marker for immature hematopoietic cells (Fig. 3A and Table 2). Of the fetal liver cells obtained from wt embryos, $>67 \%$ and $15 \%$ were c-kit-/ Ter $119^{+}$and c-kit ${ }^{+} /$Ter $119^{+}$, respectively; this suggests that a majority of the cells differentiated into erythroids (Fig. 3A). In contrast, the differentiation of erythroids was limited in the $\mathrm{ng}^{\mathrm{wt}} / \mathrm{fg}$ BMEs; $42 \%$ of the cells were c-kit ${ }^{+} /$Ter $119^{+}$and $35 \%$ were c-kit ${ }^{-} /$ Ter119 ${ }^{+}$. Furthermore, the proportion of c-kit ${ }^{+} /$Ter119- cells was significantly higher in the $\mathrm{ng}^{\mathrm{wt}} / \mathrm{fg}$ BMEs compared with that in the wt cells, i.e., $16 \%$ vs. $10 \%$. This disorder in erythroid differentiation was significantly restored in the $\mathrm{ng}^{\Delta \mathrm{ch} 7} / \mathrm{fg}, \mathrm{ng}^{\Delta \mathrm{ch} 12} / \mathrm{fg}$ and $\mathrm{ng}^{\Delta \text { Double }} / \mathrm{fg}$ BMEs, with a significant increase in the number of c$\mathrm{kit}^{-} /$Ter119 ${ }^{+}$cells (62, 61 and 65\%, respectively) and a significant decrease in the number of c-kit ${ }^{+} /$Ter $119^{+}$cells (16, 24 and 15\%, respectively; Fig. 3A, ng ${ }^{\Delta \mathrm{ch} 7} / \mathrm{fg}$ and $\mathrm{ng}^{\Delta \mathrm{ch} 12} / \mathrm{fg}$ ). The proportion of

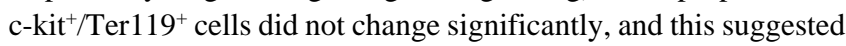
that differentiation from c-kit ${ }^{+} /$Ter $119^{+}$cells to c-kit $/$Ter119 ${ }^{+}$cells was accelerated in the $\mathrm{ng}^{\Delta \mathrm{ch} 7} / \mathrm{fg}, \mathrm{ng}^{\Delta \mathrm{ch} 12} / \mathrm{fg}$ and $\mathrm{ng}^{\Delta \text { Double}} / \mathrm{fg}$ BMEs livers.

\section{Expression of erythropoiesis related genes}

We also investigated the expression of erythroid hematopoietic marker genes in the fetal livers at E12.5 (Fig. 3B). Expression of the Gata1, EpoR, Eklf and NF-2E genes was evidently decreased in the $\mathrm{ng}^{\mathrm{wt}} / \mathrm{fg}$ and $\mathrm{ng}^{\Delta \mathrm{ch} 7} / \mathrm{fg}$ BME fetal livers. The expression levels were less than half those observed in the wt fetal livers with the exception of Eklf expression. Although the $\mathrm{ng}^{\Delta \mathrm{ch}} / \mathrm{fg}$ BMEs developed to E19.5, the expression levels of these genes did not recover. The expression levels of these genes were elevated in the $n g^{\Delta \mathrm{ch} 12} / \mathrm{fg}$ BME livers but did not recover to the levels in the wt livers. The expression of the erythroid hematopoietic markers in the $\mathrm{ng}^{\Delta \text { Double/ }}$ fg BMEs livers was increased to the levels somewhat similar to those in the wt livers (Fig. 3B). Together with the FACS data, these observations suggest that the inappropriate expression of Igf2 and Dlk1 is a major cause of definitive erythropoiesis in the $\mathrm{ng}^{\mathrm{wt}} / \mathrm{fg}$ BME fetal livers.

\section{Discussion}

In the present study, we investigated the development of the embryonic hematopoietic system in BME livers because the hematopoietic system is critical for survival of embryos beyond mid-gestation. Bi-maternal mouse embryos in which the paternally-methylated and paternally-expressed imprinted genes containing $I g f 2$ and $D l k 1$ are fundamentally repressed resulted in lethality before E13.5, accompanied by acute hematopoietic disor- 

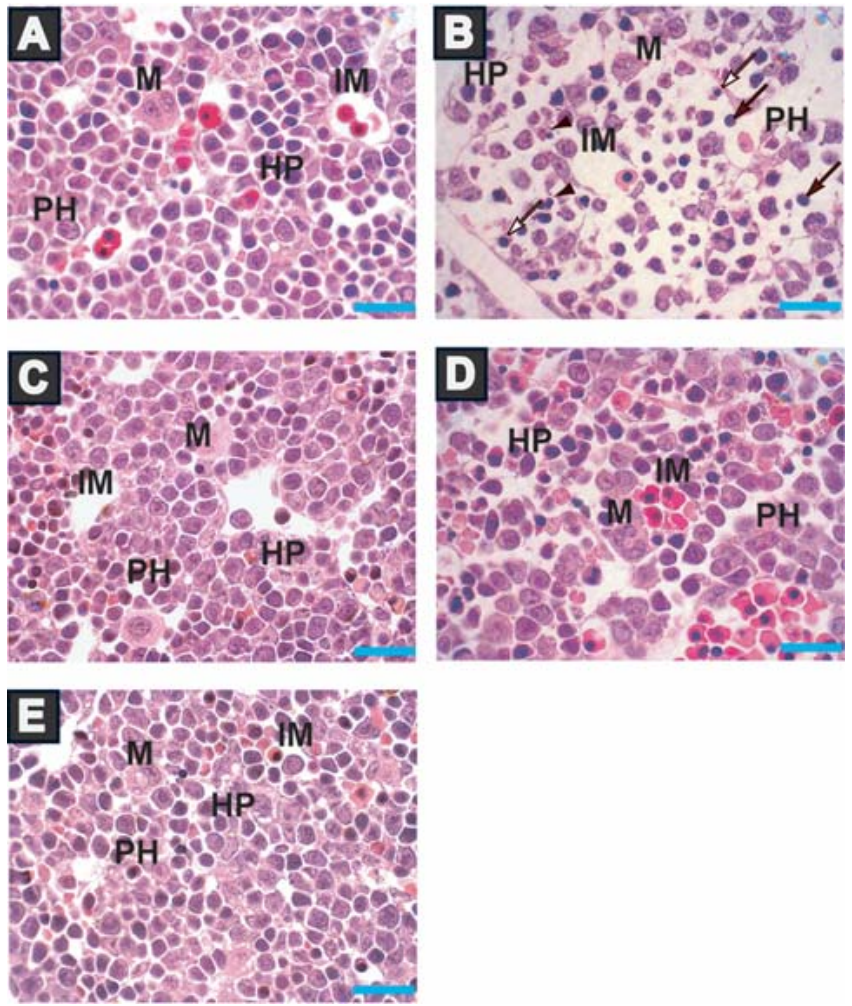

A

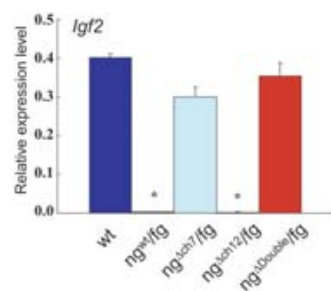

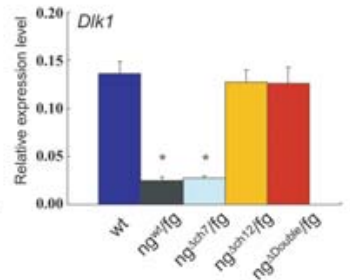

B

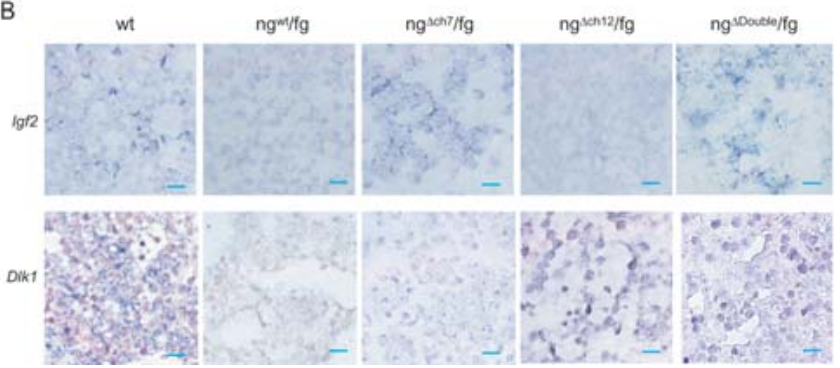

Fig. 2. Expression of the Igf2 and Dlk1 genes in the liver at E12.5. (A) Igf2 and Dlk1 expression were quantitatively analyzed by realtime PCR. The expression of each gene is shown as the average of the expression levels relative to those of the Actb gene, which was used as an internal control. Data are expressed as means \pm SEM $(n=5)$. Stars indicate significant differences from the controls $(\mathrm{P}<0.01)$. (B) Igf2 and Dlk1 expression were assessed in sections of the BMEs livers at E12.5 using in situ hybridization, and dioxigenin-labeled RNA probes were prepared using a DIG RNA labeling Kit (Roche Diagnostics GmbH, Mannheim, Germany). Scale bar=20-mm.
Fig. 1. Histological examination of the fetal livers. Sections of the fetal livers obtained from (wt) mice (A) and the $4 \mathrm{BMEs}, \mathrm{ng}^{\mathrm{wt}} / \mathrm{fg}(\mathrm{B})$, $\mathrm{ng}^{\Delta \mathrm{ch} 7} / \mathrm{fg}(\mathrm{C}), \mathrm{ng}^{\Delta \mathrm{ch} 12} / \mathrm{fg}$ (D) and $\mathrm{ng}^{\Delta \text { Double }} / \mathrm{fg}$ (E), at E12.5 stained with hematoxylin and eosin (HE). Developing parenchymal hepatocytes (PH), hematopoietic precursors (HP), intrahepatic microvessels (IM) and megakaryoblasts (M) were visible in the liver. Reduction of the cytoplasm (black arrow), condensation of the nucleus (white arrow) and fragmentation of the nucleus (arrowhead) were observed in the liver parenchyma of the $\mathrm{ng}^{\mathrm{wt}} / \mathrm{fg}$ BME (arrow). Scale bar=10-mm.

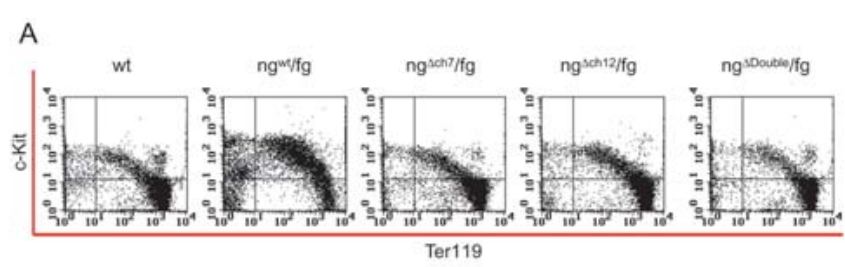

B
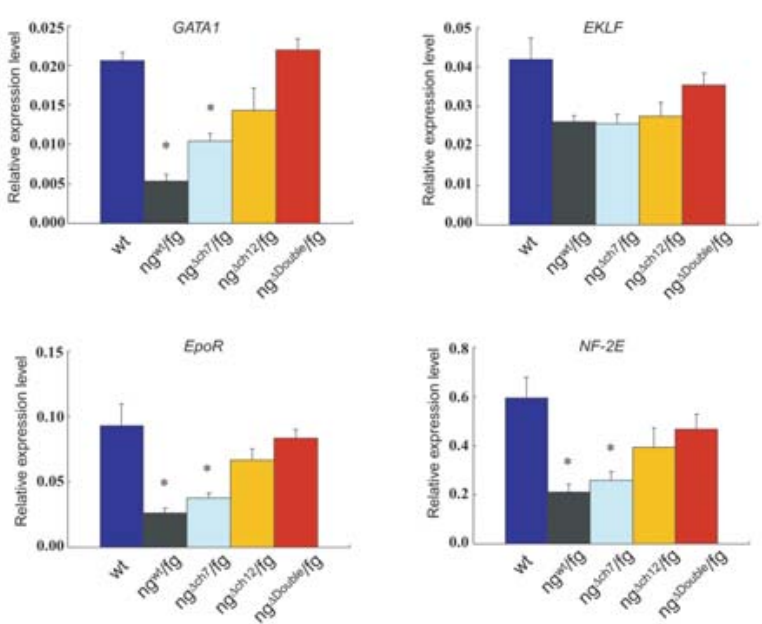

Fig. 3. Definitive erythropoiesis in the fetal liver of the $\mathrm{ng}^{\mathrm{wt}} / \mathrm{fg}, \mathrm{ng}^{\Delta \mathrm{ch} 7} / \mathrm{fg}$, $\mathrm{ng}^{\Delta \mathrm{ch12}} / \mathrm{fg}$ and $\mathrm{ng}^{\Delta \mathrm{Double}} / \mathrm{fg}$ BMEs at E12.5. (A) FACS analysis of the 3 BME livers cells at E12.5. Single fetal liver cells obtained from a wt mouse and BMEs were immunostained with antiTer119 and anti-c-Kit antibodies. Liver cells were analyzed by flow cytometry. (B) GATA1, EpoR, EKLF and NF-2E expression were quantitatively analyzed by real-time PCR. The expression of each gene is shown as the average of the expression levels relative to those of the Actb gene. Data are expressed as means \pm SEM $(n=5)$. Asterisks indicate significant differences from the controls $(\mathrm{P}<0.01)$.

ders in the liver. Experiments involving introduction of Igf2 and/or Dlk1 expression in mutant BMEs clearly demonstrated significant amelioration of fetal liver hematopoiesis.

The fetal liver functions as a major site for hematopoiesis at mid-gestation. To date several studies have reported that the imprinted Igf2 [20-24] and Dlk1 [18, 19, 25] genes are involved in the development of fetal liver hematopoiesis. During the first half of the embryonic period, the space between the hepatic cell cords 
Table 2. Proportion of fetal liver hematopoietic cells expressing Ter119 and/or C-kit

\begin{tabular}{|c|c|c|c|c|}
\hline & c-Kit ${ }^{+} /$Ter119- & c-Kit ${ }^{+} / \mathrm{Ter} 119^{+}$ & $\mathrm{c}-\mathrm{Kit}^{-} / \mathrm{Ter} 119^{-}$ & c-Kit $/$Ter119+ \\
\hline wt & $10 \pm 0.8$ & $15 \pm 0.4$ & $8 \pm 1.3$ & $67 \pm 1.5$ \\
\hline $\mathrm{ng}^{\mathrm{wt}} / \mathrm{fg}$ & $16 \pm 0.3$ & $42 \pm 7.6$ & $7 \pm 1.4$ & $35 \pm 6.6$ \\
\hline $\mathrm{ng}^{\Delta \mathrm{ch} 7} / \mathrm{fg}$ & $11 \pm 2.5$ & $16 \pm 3.7$ & $11 \pm 2.5$ & $62 \pm 3.1$ \\
\hline $\mathrm{ng}^{\Delta \mathrm{ch} 12} / \mathrm{fg}$ & $9 \pm 0.8$ & $24 \pm 0.6$ & $6 \pm 0.8$ & $61 \pm 0.6$ \\
\hline $\mathrm{ng}^{\Delta \text { Double }} / \mathrm{fg}$ & $11 \pm 1.3$ & $15 \pm 1.6$ & $10 \pm 1.4$ & $65 \pm 1.5$ \\
\hline
\end{tabular}

Values represent means \pm SD. About 10,000 cells were counted in each sample, and the analysis was repeated 3 times.

and sinusoids is filled with young mesenchymal cells, which proliferate very actively and sequentially [26]. The Igf2 gene is well known as a major regulator of fetal growth [27-29] and hematopoietic stem cell differentiation [30, 31]. IGF-II enhances the number of fetal liver stromal cells and supports in vitro erythroid colony formation [29, 32-34]. Dlk1 is relevant to fetal lethality and growth retardation in maternal disomy mice and null mutant mice [35-37]. The Dlk1 gene encodes a cell-surface transmembrane and secreted protein that is essential for normal hematopoiesis and erythroid differentiation [18, 19, 38-40]. Moore et al. [39] demonstrated that Dlk1 is activated in a cell line derived from the fetal liver, in which HSCs reproduce, and they defined a novel molecular pathway for stem cell regulation in the hematopoietic microenvironment of the fetal liver.

Erythroid differentiation in the liver of the $\mathrm{ng}^{\mathrm{wt}} / \mathrm{fg}$ BMEs was apparently retarded and accompanied by a significant increase in immature blood cells, and the Igf2 and Dlk1 genes were repressed. The present results strongly suggest that the hematopoietic defects are a major cause of death before E13.5 in the $\mathrm{ng}^{\mathrm{wt}} / \mathrm{fg}$ BMEs. Our series of studies revealed that $\mathrm{ng}^{\Delta \mathrm{ch}} / \mathrm{fg}$ and $\mathrm{ng}^{\Delta \mathrm{ch} 12} / \mathrm{fg}$ BMEs harboring mutations that allow the imprinted expression of Igf2 and Dlk1 genes, respectively, develop to term; however, both BME genotypes exhibit severe growth retardation and die soon after birth. The present results suggest that such dramatic extended development was due to effective amelioration of erythroid differentiation caused by expression of Igf2 and/or Dlk1. Together with the results of previous reports, these results suggest that Igf2 and Dlk1 are major contributors to fetal hematopoiesis and that the hematopoietic disorders are involved in developmental arrest of $\mathrm{ng}^{\mathrm{wt}} / \mathrm{fg}$ BMEs at E12.5.

Understanding the mechanism by which Igf2 and Dlk1 facilitate fetal hematopoiesis is of interest. This study provided evidence that $\mathrm{ng}^{\mathrm{wt}} / \mathrm{fg}$ BMEs result in congenital aplasia of hematopoiesis in the liver, in which the proportion of immature erythroids increases, indicating a decrease in the expression of erythroid hematopoietic marker genes. Such hematopoietic defects in the fetal liver might be caused by disorders associated with the hematopoietic microenvironment, which is necessary for HSCs in $\mathrm{ng}^{\mathrm{wt}} / \mathrm{fg}$ BMEs. It has been reported that the cell populations found in the fetal liver microenvironmental are associated with the development of hematopoiesis in mice [41], indicating that a mixed population of cells with mixed endodermal and mesodermal features corresponds to the hematopoietic-supportive fetal liver stroma. Igf2 and Dlk1, which are expressed in the stromal cells of the fetal liver, may be involved in proliferation of stromal cells and microenvironment formation. Based on these findings, we concluded that the hematopoietic defects in $n g^{\mathrm{wt}} / \mathrm{fg}$ BMEs are due to the cessation of Igf2 and/ or Dlk1 expression; this results in developmental arrest at E13.5 in ngwt/fg BMEs. We can not rule out the possibility that other genes located on chromosome 12, such as Rtl1 or Dio3, which are respectively known as a retrotransposon-like gene, with an open reading frame of unknown function and a negative regulator of thyroid hormone metabolism, might be involved in fetal hematopoiesis. However, the particular roles of both these genes in fetal hematopoiesis are completely unknown at present. Furthermore, global gene expression analysis by cDNA microarray revealed that Igf2 and Dlk1 play pivotal roles to improve the development of $\mathrm{ng} / \mathrm{fg}$ BMEs [9]. Thus, the present study suggests that Igf2 and Dlk1 predominantly function in a synergistic manner, because either gene can significantly improve the fetal liver hematopoiesis in $\mathrm{ng}^{\Delta \mathrm{ch} 7} / \mathrm{fg}$ and ng $^{\Delta \text { ch12}} /$ fg BMEs, respectively.

\section{Acknowledgments}

We thank Dr. S Tilghman (Princeton University, New Jersey, NJ, USA) and Dr. AC Ferguson-Smith (University of Cambridge, Cambridge, UK) for gifting us the mutant mice. This work was supported by grants from the Bio-oriented Technology Research Advancement Institution (BRAIN) Japan and the Ministry of Education, Culture, Sports, Science and Technology of Japan (Nos. 18208024 and 20062009).

\section{References}

1. Surani MAH, Barton SC. Development of gynogenetic eggs in the mouse: Imprications for parthnogenetic embryos. Science 1983; 222: 1034-1036.

2. Surani MAH, Barton SC, Norris ML. Development of reconstituted mouse eggs suggests imprinting of the genome during gametogenesis. Nature 1984; 308: 548-550.

3. Barton SC, Surani MA, Norris ML. Role of paternal and maternal genomes in mouse development. Nature 1984; 311: 374-376.

4. McGrath J, Solter D. Completion of mouse embryogenesis requires both the maternal and paternal genomes. Cell 1984; 37: 179-183.

5. Kono T, Obata Y, Yoshimzu T, Nakahara T, Carroll J. Epigenetic modifications during oocyte growth correlates with extended parthenogenetic development in the mouse. Nature Genet 1996; 13: 91-94.

6. Obata Y, Kaneko-Ishino T, Koide T, Takai Y, Ueda T, Domeki I, Shiroishi T, Ishino F, Kono T. Disruption of primary imprinting during oocyte growth leads to the modified expression of imprinted genes during embryogenesis. Development 1998; 125 $1553-1560$

7. Kono T, Obata Y, Wu Q, Niwa K, Ono Y, Yamamoto Y, Park ES, Seo JS, Ogawa H Birth of parthenogenetic mice that can develop to adulthood. Nature 2004; 428: 860864 .

8. Kawahara M, Wu Q, Yaguchi Y, Ferguson-Smith AC, Kono T. Complementary roles of genes regulated by two paternally methylated imprinted regions on chromosomes 7 and 12 in mouse placentation. Hum Mol Genet 2006; 15: 2869-2879. 
9. Kawahara M, Wu Q, Takahashi N, Morita S, Yamada K, Ito M, Ferguson-Smith AC, Kono $\mathrm{T}$. High frequency generation of viable mice lacking a paternal genetic contribution. Nature Biotechnology 2007; 25: 1045-1050.

10. Wu Q, Kumagai T, Kawahara M, Ogawa H, Hiura H, Obata Y, Takano R, Kono T. Regulated expression of two sets of paternally imprinted genes is necessary for mouse parthenogenetic development to term. Reproduction 2006; 131: 481-488.

11. Moore M, Metcalf $\mathbf{D}$. Ontogeny of the haemopoietic system: yolk sac origin of in vivo and in vitro colony forming cells in the developing mouse embryo. Br J Haematol 1970; 18: 279-296.

12. de Bruijn MF, Peeters MC, Luteijn T, Visser P, Speck NA, Dzierzak E. CFU-S(11) activity does not localize solely with the aorta in the aorta-gonad-mesonephros region. Blood 2000; 96: 2902-2904.

13. Medvinsky A, Dzierzak E. Definitive hematopoiesis is autonomously initiated by the AGM region. Cell 1996; 86: 897-906.

14. Muller AM, Medvinsky A, Strouboulis J, Grosveld F, Dzierzak E. Development of hematopoietic stem cell activity in the mouse embryo. Immunity 1994; 1: 291-301.

15. Ottersbach K, Dzierzak E. The murine placenta contains hematopoietic stem cells within the vascular labyrinth region. Dev Cell 2005; 8: 377-387.

16. Kumaravelu P, Hook L, Morrison AM, Ure J, Zhao S, Zuyev S, Ansell J, Medvinsky A. Quantitative developmental anatomy of definitive haematopoietic stem cells/longterm repopulating units (HSC/RUs): role of the aorta-gonad-mesonephros (AGM) region and the yolk sac in colonisation of the mouse embryonic liver. Development 2002; 129: 4891-4899.

17. Zhang CC, Lodish HF. Insulin-like growth factor 2 expressed in a novel fetal liver cell population is a growth factor for hematopoietic stem cells. Blood 2004; 103: 2513-2521.

18. Sakajiri S, O'Kelly J, Yin D, Miller CW, Hofmann WK, Oshimi K, Shih LY, Kim KH, Sul HS, Jensen CH, Teisner B, Kawamata N, Koeffler HP. Dlk1 in normal and abnormal hematopoiesis. Leukemia 2005; 19: 1404-1410.

19. Doggett KL, Briggs JA, Linton MF, Fazio S, Head DR, Xie J, Hashimoto Y, Laborda J, Briggs RC. Retroviral mediated expression of the human myeloid nuclear antigen in a null cell line upregulates Dlk1 expression. J Cell Biochem 2002; 86: 56-66.

20. Malhotra K, Luehrsen KR, Costello LL, Raich TJ, Sim K, Foltz L, Davidson S, Xu H, Chen A, Yamanishi DT, Lindemann GW, Cain CA, Madlansacay MR, Hashima SM, Pham TL, Mahoney W, Schueler PA. Identification of differentially expressed mRNAs in human fetal liver across gestation. Nucleic Acids Res 1999; 27: 839-847.

21. Li Q, Congote LF. Bovine fetal-liver stromal cells support erythroid colony formation: enhancement by insulin-like growth factor II. Exp Hematol 1995; 23: 66-73.

22. Congote LF, Li Q. Accurate processing and secretion in the baculovirus expression system of an erythroid-cell-stimulating factor consisting of a chimaera of insulin-like growth factor II and an insect insulin-like peptide. Biochem J 1994; 299: 101-107.

23. Sanders M, Sorba S, Dainiak N. Insulin-like growth factors stimulate erythropoiesis in serum-substituted umbilical cord blood cultures. Exp Hematol 1993; 21: 25-30.

24. Morison IM, Eccles MR, Reeve AE. Imprinting of insulin-like growth factor 2 is modulated during hematopoiesis. Blood 2000; 96: 3023-3028.

25. Li L, Forman SJ, Bhatia R. Expression of DLK1 in hematopoietic cells results in inhibition of differentiation and proliferation. Oncogene 2005; 24: 4472-4476.
26. Sasaki K, Sonoda Y. Histometrical and three-dimensional analyses of liver hematopoiesis in the mouse embryo. Arch Histol Cytol 2000; 63: 137-146.

27. DeChiara TM, Robertson EJ, Efstratiadis A. Parental imprinting of the mouse insulin-like growth factor II gene. Cell 1991; 64: 849-859.

28. Nunez C, Bashein AM, Brunet CL, Hoyland JA, Freemont AJ, Buckle AM, Murphy C, Cross MA, Lucas G, Bostock VJ, Brady G. Expression of the imprinted tumoursuppressor gene H19 is tightly regulated during normal haematopoiesis and is reduced in haematopoietic precursors of patients with the myeloproliferative disease polycythaemia vera. J Pathol 2000; 190: 61-68.

29. Hiroyama T, Miharada K, Aoki N, Fujioka T, Sudo K, Danjo I, Nagasawa T, Nakamura $\mathrm{Y}$. Long-lasting in vitro hematopoiesis derived from primate embryonic stem cells. Exp Hematol 2006; 34: 760-769.

30. Zhang J, Socolovsky M, Gross AW, Lodish HF. Role of Ras signaling in erythroid differentiation of mouse fetal liver cells: functional analysis by a flow cytometry-based novel culture system. Blood 2003; 102: 3938-3946.

31. Eckardt S, Leu NA, Bradley HL, Kato H, Bunting KD, McLaughlin KJ. Hematopoietic reconstitution with androgenetic and gynogenetic stem cells. Genes Dev 2007; 21: 409-419.

32. Dainiak N, Sanders M, Sorba S. Induction of circulating neonatal stem cell populations. Blood Cells 1991; 17: 339-343.

33. Greenberg PL. Effects of insulin-like growth factors on hemopoiesis. Blood Cells 1991 17: $344-348$.

34. Schwartz GN, Warren MK, Sakano K, Szabo JM, Kessler SW, Pashapour A, Gress RE, Perdue JF. Comparative effects of insulin-like growth factor II (IGF-II) and IGF-II mutants specific for IGF-II/CIM6-P or IGF-I receptors on in vitro hematopoiesis. Stem Cells 1996; 14: 337-350.

35. Lin SP, Youngson N, Takada S, Seitz H, Reik W, Paulsen M, Cavaille J, FergusonSmith AC. Asymmetric regulation of imprinting on the maternal and paternal chromosomes at the Dlk1-Gt12 imprinted cluster on mouse chromosome 12. Nat Genet 2003; 35: 97-102.

36. Georgiades P, Watkins M, Surani MA, Ferguson-Smith AC. Parental origin-specific developmental defects in mice with uniparental disomy for chromosome 12. Development 2000; 127: 4719-4728.

37. Moon YS, Smas CM, Lee K, Villena JA, Kim KH, Yun EJ, Sul HS. Mice lacking paternally expressed Pref-1/Dlk1 display growth retardation and accelerated adiposity. Mol Cell Biol 2002; 22: 5585-5592.

38. Moore T. Genetic conflict, genomic imprinting and establishment of the epigenotype in relation to growth. Reproduction 2001; 122: 185-193.

39. Moore KA, Pytowski B, Witte L, Hicklin D, Lemischka IR. Hematopoietic activity of a stromal cell transmembrane protein containing epidermal growth factor-like repeat motifs. Proc Natl Acad Sci USA 1997; 94: 4011-4016.

40. Laborda J. The role of the epidermal growth factor-like protein dlk in cell differentiation. Histol Histopathol 2000; 15: 119-129.

41. Chagraoui J, Fau-Lepage-Noll A, Lepage-Noll A, Fau-Anjo A, Anjo A Fau-Uzan G, Uzan G Fau-Charbord P, Charbord P. Fetal liver stroma consists of cells in epithelialto-mesenchymal transition. Bood 2003: 2973-2982. 